Available online at www.sciencerepository.org

Case Report and Review of the Literature

\title{
Multidisciplinary Approach to Acute Cholecystitis in a Severely Cardiopathic Patient: Case Report and Review of Literature on Treatment Strategies
}

\section{Desirè Pantalone $^{1^{*}}$, Giovanni Alemanno ${ }^{2}$, PierLuigi Stefano ${ }^{3}$, Stefano Del Pace ${ }^{4}$, Stefano Romagnoli ${ }^{5}$, Paolo} Boninsegni $^{6}$, Carlo Rostagno ${ }^{7}$, Massimo Bonacchi $^{8}$, Gherardo Maltinti $^{2}$, Alessandro Bruscino ${ }^{2}$, Carlo Bergamini ${ }^{2}$, Jacopo Martellucci ${ }^{2}$, Luca.Talamucci ${ }^{9}$, Francesco Mondaini $^{10}$, Claudia Ranalli ${ }^{11}$ and Paolo Prosperi ${ }^{12}$

${ }^{1}$ Fellow of the American College of Surgeons, Assistant Professor in General Surgery, Department of Experimental and Clinical Medicine, University of Florence, Specialist in Vascular Surgery, Emergency Surgery Unit, Trauma Team, Emergency Department, Careggi University Hospital, Florence, Italy

${ }^{2}$ Emergency Surgery Unit, Trauma Team, Emergency Department, Careggi University Hospital, Florence, Italy

${ }^{3}$ Associate Professor of Cardiac Surgery, Director of the School in Cardiac Surgery, Department of Experimental and Clinical Medicine, University of Florence, Head of Cardiovascular Surgery Unit, Cardio-Thoracic and Vascular Department, Careggi University Hospital, Florence, Italy

${ }^{4}$ Head of the Cardiac Surgery Management Unit, Cardio-Thoracic and Vascular Department, Careggi University Hospital, Florence, Italy ${ }^{5}$ Associate Professor of Anesthesiology and Acute Care, Department of Health Sciences, University of Florence, Unit of Anesthesiology and Acute Care, Careggi University Hospital, Florence, Italy

${ }^{6}$ Head of the Anesthesiology and Resuscitation Unit, "Nuovo San Giovanni Di Dio" Hospital, Florence, Italy

${ }^{7}$ Associate Professor of Internal Medicine, Department of Experimental and Clinical Medicine, University of Florence, Head of Internal and Post-Surgical Medicine Unit, Careggi University Hospital, Florence, Italy

${ }^{8}$ Associate Professor of Cardiac Surgery, Department of Experimental and Clinical Medicine, University of Florence, Specialist in Cardiology, Cardiac Surgery Unit, Careggi University Hospital, Florence, Italy

${ }^{9}$ Advanced Interventional Endoscopy Unit, Careggi University Hospital, Florence, Italy

${ }^{10}$ Department of Vascular and Interventional Radiology, Careggi University Hospital, Florence, Italy

${ }^{11}$ Internal and Post-Surgical Medicine Unit, Careggi University Hospital, Florence, Italy

${ }^{12}$ Head of Emergency Surgery Unit, Trauma Team, Emergency Department, Careggi University Hospital, Florence, Italy

\footnotetext{
${ }^{*}$ Correspondence to: Desirè Pantalone, F.A.C.S., Fellow of the American College of Surgeons, Assistant Professor in General Surgery, Department of Experimental and Clinical Medicine, University of Florence, Specialist in Vascular Surgery, Emergency Surgery Unit, Trauma Team, Emergency Department, Careggi University Hospital, Florence, Italy; E-mail: desire.pantalone@unifi.it
}

(C) 2020 Desirè Pantalone. This is an open-access article distributed under the terms of the Creative Commons Attribution License, which permits unrestricted use, distribution, and reproduction in any medium, provided the original author and source are credited. Hosting by Science Repository. http://dx.doi.org/10.31487/j.SCR.2020.12.10 


\section{A R T ICLE INFO}

\begin{tabular}{l}
\hline Article history: \\
Received: 13 November, 2020 \\
Accepted: 26 November, 2020 \\
Published: 11 December, 2020 \\
\hline Keywords: \\
St Jude ring \\
acute calculous cholecystitis \\
myocardial infarction \\
interventricular septum rupture \\
Kay procedure \\
CABG \\
cholecystectomy \\
percutanous cholecystostomy \\
choledochus stones \\
ERCP
\end{tabular}

\begin{abstract}
A B S T R A C T
Acute cholecystitis in severely cardiopathic patients after major cardiac surgery represents a challenge for surgeons. Treatment with cholecystostomy, may offer a chance to these patients, however there is still a number of controversial issues on the topic: performance surgical techniques (transhepatic or transpapillary), optimal duration and timing of drain removal, the need for further tests before removal as well as the timing for definitive surgery. We therefore deemed it important to share our experience of a multidisciplinary approach for the definitive treatment of this patient with severe heart disease. A percutaneous cholecystostomy was the chosen strategy for a 58-year-old cardiopathic patient who had undergone surgery for hip replacement and had developed acute calculous cholecystitis a few days after surgery. Two weeks after discharge, a cholangiography through the cholecystostomy and an MRI cholangiopancreatography revealed the presence of stones in the cystic duct and in the ductus choledochus. The definitive treatment was decided after consulting with a multidisciplinary team. The choice was to perform an open cholecystectomy with simultaneous removal of the cholecystostomy, endoscopic removal of stones and sphincterotomy of the Oddi papilla. Currently, the patient is healthy and his heart function satisfactory. Although early cholecystectomy is the recommended choice for acute cholecystitis, a patient with severe co-morbidities may benefit from a bridging therapy before definitive surgery and a multidisciplinary approach can provide a safer solution.
\end{abstract}

\section{Introduction}

In case of patients unfit for surgery (due to co-morbidities) the Tokio Guidelines (TG) 2018 recommend the use of percutaneous cholecystostomy (PC) both in grade II and III cholecystitis because this method allows to convert a septic cholecystitis into a non-septic situation with a reduction of inflammation and improvement in clinical condition $[1,2]$. However the WSES guidelines reported lack of higher level evidence ( $\operatorname{LoE} 4, \mathrm{GoR} C)$ on this topic [3, 4]. In general, an analysis of the relevant literature confirmed this lack and the need for randomized clinical trials. There are still controversial issues regarding cholecystostomy: the techniques used to perform it (transhepatich or transpapillary), optimal duration and removal time, indications for further examinations prior to removal and finally, the optimal timing of definitive surgery.

In this paper, we report the case of a patient presenting with acute calculous cholecystitis following recent hip replacement, who had undergone several complex cardiac surgical procedures for myocardial infarction with interventricular septal rupture 18 months earlier. We deemed it important to share our experience in this case of acute cholecystitis in a severe cardiopathic patient, providing an overview of the literature on the treatment with PC insertion as a bridge therapy as well as recognizing the value of a multidisciplinary team in finding the definitive therapy

\section{Case Report}

A 58-year-old man with cardiopathy, admitted to the Internal and Postsurgical Medicine Unit of our hospital, presented with calcolous cholecystitis during the postoperative course following the prosthetic replacement of the femoral head under spinal anaesthesia performed in June 2019. The calculous cholecystitis was confirmed by ultrasound examination and CT scan, that showed a fluid collection around the gallbladder with delaminated walls and presence of stones. Leukocytosis and abdominal pain were also present. The patient's home therapy included: oral assumption of aspirin, bisoprolol, furosemide, ivabradine, metolazone, potassium canrenoate after the emergency cardiac surgery for acute post-myocardial infarction rupture in the posterior portion of the interventricular septum (IVSR) he had undergone about 18 months earlier. For the surgical repair, a bovine pericardial patch was used ("infarction exclusion technique") through the left ventricular posterior wall and a concomitant coronary artery bypass graft (CABG) with the left internal mammary artery anastomosed sequentially to the left anterior descending artery and the first diagonal branch.

The postoperative cardiac echocolordoppler showed a significant postoperative residual left-to-right shunt and therefore a new elective treatment was planned. A month after surgery, a percutaneous attempt was carried out (with Amplatzer VSD Muscular Occluder n. 18mm) to close the residual IVSR but it was unsuccessful, and a redo surgery was needed. In this instance, after the implantation of an Intra-Aortic Balloon Pump (IABP), the septum was repaired through the tricuspid valve. A mitral valve annuloplasty (with St Jude ring n. 26mm) and tricuspid valve annuloplasty (by the Kay-technique) were also required. The postoperative course was uneventful except for the onset of a marked bradycardia that required pacemaker implantation. At the time of the hospital discharge, the patient was symptomless and in a good and stable hemodynamic status. The cardiac ultrasound examination showed a residual mild left-to-right shunt, a moderate right ventricular dysfunction and a left ventricular ejection fraction of 35\%. Follow-up outpatient checkups confirmed the stability of the patient's hemodynamic and clinical status.

At the time of acute cholecystitis, due to the high risk cardiac condition, a bridging procedure with placement of a percutaneous cholecystostomy (PC) was the chosen strategy. PC was performed transhepatically under local anaesthesia by our Interventional Radiologists Team. Two weeks after discharge, a cholangiography through the cholecystostomy revealed the presence of stones in the cystic duct and in the ductus choledochus, confirmed by MRI cholangiopancreatography. The 
definitive treatment was decided after consulting with a multidisciplinary team composed of cardiac surgeons, cardiologists, anaesthesiologists and endoscopists.

His cardiac condition was checked once again before surgery, revealing $31 \%$ ejection fraction (EF), slight pulmonary hypertension, minimal tricuspid valve insufficiency. The intraoperative phase was managed using advanced hemodynamic and anaesthesia monitoring that included pulse contour analysis to determine the continuous cardiac output (MostCare $^{\mathrm{UP}}$, Vygon, Caen, France), trans-esophageal echocardiography, and depth of anaesthesia monitoring (Sedline ${ }^{\circledR}$, Masimo, Irvine, CA, USA). An open cholecystectomy was performed with the simultaneous removal of the cholecystostomy tube, endoscopic extraction of stones and sphincterotomy of the Oddi papilla. After surgery, the patient was transferred to the general Intensive Care Unit and then to the Cardiac Surgery Unit from which he was discharged in satisfactory health condition on the tenth postoperative day. He is presently healthy and in good shape.

\section{Discussion and Conclusion}

An initial literature search on the subject 'Cholecystostomy' and "Cholecystitis surgical treatment" produced several observational studies, a systematic review, a propensity score analysis in elderly and a Cochrane Systematic review [5-30]. The selection criteria used for the observational studies, but also results and often the conclusions reached by various Authors were found to be largely non-homogeneous. The systematic review stated that PC was performed after failure of medical treatment and was associated to unacceptably high rates of complications and mortality [28]. The propensity score study, that showed a lower rate of definitive cholecystectomy and a higher mortality and readmission rate, concluded that a refinement to the Tokio guidelines was needed on this topic [29]. The Cochrane Systematic Review confirmed a lack of clear indications for the use of PC in the clinical management of high risk surgical patients with cholecystitis and underlined the need of randomized clinical trials [30].

Regarding cholecystostomy placement techniques, although according to TG2018 transhepatic percutaneous cholecystostomy remains the recommendation, it is also worth examining a systematic review and a propensity score paper found in the literature [1, 31-34]. The first compared EUS-guided gallbladder drainage (EUS-GBD) vs endoscopic transpapillary gallbladder drainage (ET-GBD), showing that EUS-GBD was the better choice because of higher rate of technical and clinical success and lower rate of recurrent cholecystitis [33]. The second paper compared percutaneous and endoscopic gallbladder drainage [34] Results showed that there were no significant differences between the two techniques in clinical efficacy and complication rate.

Also the optimal duration of PC drainage, as reported in a paper by Hasbahceci et al. is still a controversial issue [8]. The suggested time is considered to be three to six weeks, with an average of one month, but Morse et al. recommended that the PC tube should remain in place in critically ill patients until cholecystectomy (Table 1) [11]. The same was suggested by Wang et al. [35]. However, other studies reported adverse events, one of them indicating that a drainage duration longer than two weeks may be associated with increased recurrence rate [6]. Other policies have been catheter removal after confirmation of the patency of the cystic duct [33]. Discharge with the PC tube in place until cholecystectomy has also been reported [6]. So far, no definitive conclusion has been drawn on timing, although catheter removal can generally be performed after temporary clamping [10]. Some Authors left the PC tube in place as a bridge procedure and performed early surgery after a mean of $9.68 \pm 6.45$ days [11]. However, further studies are needed to clarify the timing of PC tube removal before definitive surgery. Furthermore, recurrence after catheter removal is an important issue in patients not undergoing surgical treatment $[6,8,11]$.

Table 1: Articles (2010-2020) reporting a time interval between cholecystostomy and cholecystectomy.

\begin{tabular}{|c|c|c|c|}
\hline Author & Title & Journal & $\begin{array}{l}\text { Timing for cholecystostomy removal an } \\
\text { definitive cholecystectomy }\end{array}$ \\
\hline $\begin{array}{l}\text { De Geus T et al. [47] } \\
2020\end{array}$ & $\begin{array}{l}\text { Outcomes of patients treated with upfront } \\
\text { cholecystostomy for severe acute choelcystytis. }\end{array}$ & \begin{tabular}{|l|} 
Surg Laparosc Endosc percutan \\
Tech 2020;30:79-84
\end{tabular} & No timing definition reported \\
\hline $\begin{array}{l}\text { Masrani A et al. } \text { [17] } \\
2020\end{array}$ & $\begin{array}{l}\text { Management algorithm of acute cholecystitis after } \\
\text { percutaneous cholecystostomy catheter placement } \\
\text { based on outcomes from } 377 \text { patients }\end{array}$ & $\begin{array}{l}\text { Abdominal radiology } \\
\text { 20205:1193-1197 }\end{array}$ & $\begin{array}{l}\text { Cholangiography after two weeks, no } \\
\text { definite timing for catheter removal and } \\
\text { delayed cholecystectomy }\end{array}$ \\
\hline $\begin{array}{l}\text { Alotaibi A et al. [48] } \\
2019\end{array}$ & $\begin{array}{l}\text { Is cholecystostomy e real bridge for cholecystectomy } \\
\text { ub acute cholecystitis. A retrospective cohort study }\end{array}$ & $\begin{array}{l}\text { Saudi J Health Sci 2019;8:157- } \\
61\end{array}$ & No timing definition reported \\
\hline $\begin{array}{l}\text { Aroori S et al. }[5] \\
2019\end{array}$ & $\begin{array}{l}\text { Percutanous cholecystostomy for severe acute } \\
\text { cholecystitis: a useful procedure in high-risk patients } \\
\text { for surgery. }\end{array}$ & $\begin{array}{l}\text { Scandinavian Journal of Surgery } \\
\text { 2019, Vol. 108(2) } 124-129 . \\
\text { DOI: } \\
10.1177 / 1457496918798209 \\
\end{array}$ & $\begin{array}{l}\text { Removal of the cholecystostomy after } 6 \\
\text { weeks and concurrent cholecistectomy }\end{array}$ \\
\hline $\begin{array}{l}\text { Pal I et al. }[21] \\
2018\end{array}$ & $\begin{array}{l}\text { Role of percutaneous cholecystostomy tube placement } \\
\text { in the management of acute calculus cholecystitis in } \\
\text { high risk patients }\end{array}$ & JCPSP 2018;28 (5):386-389 & 6-8 weeks after cholecystostomy placement \\
\hline $\begin{array}{l}\text { Kim D et al. }[15] \\
2018\end{array}$ & $\begin{array}{l}\text { Expanding role of percutaneous cholecystostomy and } \\
\text { interventional radiology for the management of acute } \\
\text { cholecystitis: An analisys of } 144 \text { patients }\end{array}$ & $\begin{array}{l}\text { Diagnost Intervent Imaging } \\
\text { 2018;99:15-21 }\end{array}$ & No timing definition reported \\
\hline
\end{tabular}




\begin{tabular}{|c|c|c|c|}
\hline $\begin{array}{l}\text { Hasbahceci M et al. } \\
{[8] 2018}\end{array}$ & $\begin{array}{l}\text { The impact of a percutaneous cholecystostomy } \\
\text { catheter in situ until the time of cholecystectomy on } \\
\text { the development of recurrent acute cholecystitis: a } \\
\text { historical cohort study }\end{array}$ & $\begin{array}{l}\text { Rev Esp Enferm Dig } \\
\text { 2018:110(10):629-633. DOI: } \\
\text { 10.17235/reed.2018.5644/2018 }\end{array}$ & $\begin{array}{l}\text { 6-8 weeks after cholecystostomy placement } \\
\text { (3 groups:1)PC no further treatment,2) } \\
\text { removal of the PC and subsequent } \\
\text { cholecystectomy,3) PC left in situ until } \\
\text { removal at the beginning of surgery) }\end{array}$ \\
\hline $\begin{array}{l}\text { Dai Y et al. [49] } \\
2017\end{array}$ & $\begin{array}{l}\text { Current status of percutaneous cholecystostomy for } \\
\text { the management of cholecystitis }\end{array}$ & Dig Div Interv 2017;1:22-27 & No timing definition reported \\
\hline $\begin{array}{l}\text { Zeren S et al. }[50] \\
2017\end{array}$ & $\begin{array}{l}\text { Bridge treatment for early cholecystectomy in geriatric } \\
\text { patients with acute cholecystitis:percutaneous } \\
\text { cholecystostomy }\end{array}$ & $\begin{array}{l}\text { Ulus Trauma Acil Cerrahi Derg } \\
\text { 2017;23 (6):501-505 }\end{array}$ & No timing definition reported \\
\hline $\begin{array}{l}\text { Bala M et al. }[51] \\
2016\end{array}$ & $\begin{array}{l}\text { Percutaneous cholecystostomy is safe and effective } \\
\text { option for acute cholecystitis in select group of high- } \\
\text { risk patients }\end{array}$ & $\begin{array}{l}\text { Eur J Trauma Emerg Surg } \\
\text { 2016;42:761-766 }\end{array}$ & No timing definition reported \\
\hline $\begin{array}{l}\text { Popowicz A et al. } \\
{[12]} \\
2016\end{array}$ & $\begin{array}{l}\text { Cholecystostomy as Bridge to Surgery and as } \\
\text { Definitive Treatment or Acute Cholecystectomy in } \\
\text { Patients with Acute Cholecystitis }\end{array}$ & $\begin{array}{l}\text { Gastroenterology Research and } \\
\text { Practice 2016, Article ID } \\
3672416, \\
\text { http://dx.doi.org/10.1155/2016/3 } \\
672416 \\
\end{array}$ & No timing definition reported \\
\hline $\begin{array}{l}\text { Suzuki K et al. [20] } \\
2015\end{array}$ & $\begin{array}{l}\text { Tube cholecystostomy before cholecystectomy for the } \\
\text { treatment of acute cholecystitis }\end{array}$ & \begin{tabular}{|l|l|} 
JSLS2015(19)1 \\
DOI:10.4293/JSLS.2014.00200 \\
\end{tabular} & No timing definition reported \\
\hline $\begin{array}{l}\text { Jung W et al. }[16] \\
2015\end{array}$ & $\begin{array}{l}\text { Timing of cholecystectomy after percutaneous } \\
\text { cholecistostomy for acute cholecystitis }\end{array}$ & \begin{tabular}{|l|} 
Korean J Gastroenterol \\
$2015 ; 66: 209-214$ \\
\end{tabular} & $\begin{array}{l}\text { No timing definition reported } \\
\text { (patients diveded in two group: group1 } \\
\text { mild disease had surgery within } 10 \text { days. } \\
\text { Group } 2 \text { moderate disease had surgery after } \\
10 \text { days }\end{array}$ \\
\hline $\begin{array}{l}\text { Jang WS et al. }[10] \\
2015\end{array}$ & $\begin{array}{l}\text { Outcome of conservative percutaneous } \\
\text { cholecystostomy in high-risk patients with acute } \\
\text { cholecystitis and risk factors leading to surgery }\end{array}$ & $\begin{array}{l}\text { Surg Endosc 2015;29:2359-64. } \\
\text { DOI: } 10.1007 / \text { s00464-014- } \\
\text { 3961-4 11. }\end{array}$ & \begin{tabular}{|l|} 
Laparoscopic cholecystectomy within 7 \\
days after PC or more than 7 days after PC \\
placement
\end{tabular} \\
\hline $\begin{array}{l}\text { Mizrahi I et al. }[52] \\
2015\end{array}$ & $\begin{array}{l}\text { Perioperative outcomes of delayed laparoscopic } \\
\text { cholecystectomy for acute with and without } \\
\text { percutaneous cholecystostomy }\end{array}$ & Surgery $2015 ; 158: 728-35$ & 6-8 weeks after PC placement \\
\hline $\begin{array}{l}\text { Sanjay P et al. }[19] \\
2013\end{array}$ & $\begin{array}{l}\text { Clinical outcomes of a percutaneous cholecystectomy } \\
\text { for acute cholecystitis:a multicentre analysis }\end{array}$ & HPB 2013;15:511-516 & 4-6-weeks after PC placement \\
\hline $\begin{array}{l}\text { Hsieh YC et al. [6] } \\
2012\end{array}$ & $\begin{array}{l}\text { Outcome after percutaneous cholecystostomy for } \\
\text { acute cholecystitis: a single-center experience }\end{array}$ & $\begin{array}{l}\text { J Gastrointest Surg } \\
\text { 2012;16:1860-8. DOI: } \\
\text { 10.1007/s11605-012-1965-8 } \\
\end{array}$ & $\begin{array}{l}\text { 8-10days from PC insertion after } \\
\text { symtomatology resolution }\end{array}$ \\
\hline $\begin{array}{l}\text { Morse BC et al. }[11] \\
2010\end{array}$ & $\begin{array}{l}\text { Management of acute cholecystitis in critically ill } \\
\text { patients: contemporary role for cholecystostomy and } \\
\text { subsequent cholecystectomy }\end{array}$ & Am Surg 2010;76:708-12 & $\begin{array}{l}\text { small patient population. In critically ill } \\
\text { patients, cholecystostomy tubes should } \\
\text { remain in place until the patient is suitable } \\
\text { to undergo cholecystectomy. Removal of } \\
\text { the cholecystostomy tube without } \\
\text { subsequent cholecystectomy is associated } \\
\text { with a high incidence of recurrent } \\
\text { cholecystitis and devastating consequences. }\end{array}$ \\
\hline $\begin{array}{l}\text { Chok KS et al. }[18] \\
2010\end{array}$ & $\begin{array}{l}\text { Results of percutaneous transhepatic cholecystostomy } \\
\text { for high surgical risk patients with acute cholecystitis }\end{array}$ & $\begin{array}{l}\text { ANZ J Surg 2010;80:280-3. } \\
\text { doi:10.1111/j.1445- } \\
\text { 2197.2009.05105.x }\end{array}$ & No timing definition reported \\
\hline $\begin{array}{l}\text { Koebrugge B et al. } \\
{[9] 2010}\end{array}$ & $\begin{array}{l}\text { Percutaneous cholecystostomy in critically ill } \\
\text { patientswith cholecystitis: a sale option }\end{array}$ & Dig Surg 27:417-421, 2010 & No timing definition reported \\
\hline
\end{tabular}

Both the 2016 WSES guidelines on acute cholecystitis, and in the 2017 WSES and SICG guidelines on acute calculous cholecystitis in the elderly, mentioned the CHOCOLATE study, an ongoing multicentre randomized clinical trials on laparoscopic cholecystectomy versus percutaneous catheter drainage for acute cholecystitis in high risk patients [3, 4, 36, 37]. In 2018 Loozen et al. reported that the definitive results of the CHOCOLATE study stated that while the mortality rate, one of the primary endpoints of the study, did not differ significantly between the two groups, (percutaneous cholecystostomy vs early cholecystectomy $(\mathrm{P}=0.27)$, differences were significant in the other primary endpoint, i.e. the occurrence of major complications, in favour of early cholecystectomy (risk ratio $0.19,95 \%$ confidence interval 0.10 to $0.37, \mathrm{P}=0,001$ ) [37]. The conclusion was that among high risk patients 
with acute cholecystitis, cholecystectomy was the preferred treatment over percutaneous cholecystostomy.

However, the rate of recurrent gallstone related symptoms could have been lower if all the patients with drainage had undergone definitive elective cholecystectomy. The CHOCOLATE study did not explore the possibility of cholecystectomy after PC placement, due to the fact that PC by itself is considered the best definitive treatment for avoiding surgical complications [18, 37-40]. To the best of our knowledge, no studies are presently available on clinical, biochemical or radiological predictors for failure of percutaneous catheter drainage in acute cholecystitis.

As to the high risk assessment of individual patients some authors report that in patients with an ASA score grade III and IV, PC is a minimally invasive treatment with a low complication rate for patients with ACC $[5,6,10]$. In particular, in a retrospective study Aroori et al. examined 53 patients who had undergone PC [5]. Patients fit enough for surgery had the PC removed at the time of surgery and a definitive cholecystectomy was performed after 6 weeks. Despite the fact that, based on the risk assessment over $50 \%$ of the patients were ASA IV and $\mathrm{V}$, the majority survived and underwent the PC procedure. The associated presence of common bile duct stone (Choledocholithiasis) at presentation, has been reported to occur in $10-20 \%$ in case series of cholelithiasis, with a lower incidence during ACC ranging from 5-15\% of the patients [35, 41, 42].

The American Society of Gastrointestinal Endoscopy and the Society of American Gastrointestinal Endoscopic Surgeons of risk stratification of common bile duct stones (CBDS) defined three different classes: low risk $(<10 \%)$, moderate (10 to 50\%) and high risk (> 50\%), (ASGE 2010) $[43,44]$. Patients with a low risk of CBDS should be operated upon without further investigation. Patients with moderate risk should undergo a second level examination, i.e., preoperative endoscopic ultrasound (EUS) or preoperative magnetic resonance cholangiopancreatography (MRCP) or intraoperative laparoscopic ultrasound or laparoscopic cholangiography. Depending on the different clinical conditions assessed, patients shall undergo stone removal prior, during or after surgery. Patients at high risk for CBDS should directly proceed to preoperative diagnostic and therapeutic ERCP. With regard to preoperative imaging techniques, Magnetic Resonance Cholangiopancreatography and Endoscopic Ultrasound are the diagnostic procedures of choice.

Intraoperative cholangiography is an invasive procedure with potential severe complications. Positive findings on intraoperative cholangiography lead to intraoperative management of CBDS with prolonged operative time. In this case we utilized ERCP plus sphincterotomy as a combination of intraoperative procedure with the rendezvous technique $[1,11,25]$. Its morbidity includes pancreatitis, cholangitis, hemorrhage, duodenal perforation or allergy to contrast. However, while intraoperative cholangiography significantly increases the length of surgery intraoperative ERCP plus sphincterotomy reduce risks for post-ERCP pancreatitis [1,3]. Both the procedures require a dedicated staff in the operating room.
This case presented the following critical points:

i. The choice of a multidisciplinary approach to select the best management in difficult clinical cases.

ii. The evaluation of the patient's heart conditions related to a reduced $\mathrm{EF}$, a persistent ventricular septal defect due to previous myocardial infarction with ventricular septal rupture that had required numerous surgical repairs and pacemaker placement.

iii. The choice of PC for first line treatment as a bridge procedure to manage the acute situation before definitive treatment.

iv. The choice of a delayed open cholecystectomy with cholecystostomy tube removal at the time of surgery associated to a rendezvous for the removal of biliary stones from the Common Biliary Duct (CBD) and simultaneous endoscopic sphincterotomy for Oddi dysfunction.

The choice at presentation for acute cholecystitis of a bridging procedure was decided autonomously by the surgeon on call as the best solution to solve the acute condition before definitive surgery. This choice is supported by several studies suggesting that PC followed by laparoscopic cholecystectomy is a suitable management for patients with ACC who are deemed unfit for emergency surgery $[8,12,45]$. In a paper of 2016, Popowicz et al., reviewed the medical reports of seven hospitals with 799 pts. admitted in 2003 and 850 in 2008 [12]. Multivariate regression analysis was performed with adjustments for age, gender, degree of cholecystitis and Charlson comorbidity index [46]. Notably, although patients treated with cholecystectomy as a bridge to elective surgery, were older with a predominance of females, the complications reported in the "bridge to surgery" group were entirely confined to the subsequent final gallbladder operation, confirming the Authors' conclusion that PC is a safe option in high risk patients with ACC. The only negative finding was the longer hospital stay in the PC group.

The multidisciplinary teamwork collaboration enabled the sharing of information about the patient's health, from the initial myocardial infarction to the required cardiac surgical procedures, up to the removal of the gallbladder. This allowed to find a definitive cure and eliminate a potential infection starter in a severe cardiopathic patient. The strategic adoption of a step by step procedure with PC as bridging therapy before definitive cholecystectomy supported by medical and surgical teamwork from different specialties has proven to be a valuable approach in providing the best treatment option for this high risk patient.

\section{Acknowledgment}

The Authors thank Patrizia Agresti, registered translator at the Courthouse of Florence, for her help in checking and revising the english version of this manuscript.

\section{Conflicts of Interest}

None.

\section{REFERENCES}

1. Okamoto K, Suzuki K, Takada T, Strasberg SM, Asbun HJ et al. (2018) Tokyo Guidelines 2018: flowchart for the management of acute cholecystitis. J Hepatobiliary Pancreat Sci 25: 55-72. [Crossref] 
2. Mori Y, Itoi T, Baron TH, Takada T, Strasberg SM et al. (2018) Tokyo Guidelines 2018: Management strategies for gallbladder drainage in patients with acute cholecystitis (with videos). J Hepatobiliary Pancreat Sci 25: 87-95. [Crossref]

3. Ansaloni L, Pisano M , Coccolini F, Peitzmann AB, Fingerhut A et al. (2016) 2016 WSES guidelines on acute calculous cholecystitis. World J Emerg Surg 11: 25. [Crossref]

4. Pisano M, Ceresoli M, Cimbanassi S, Gurusamy K, Coccolini F et al. (2019) 2017 WSES and SICG guidelines on acute calcolous cholecystitis in elderly population. World J Emerg Surg 14: 10. [Crossref]

5. Aroori S, Mangan C, Reza L, Gafoor N (2019) Percutanous cholecystostomy for severe acute cholecystitis: a useful procedure in high-risk patients for surgery. Scand J Surg 108: 124-129. [Crossref]

6. Hsieh YC, Chen CK, Su CW, Chan CC, Huo TI et al. (2012) Outcome after percutaneous cholecystostomy for acute cholecystitis: a singlecenter experience. J Gastrointest Surg 16: 1860-1868. [Crossref]

7. Zarour S, Imam A, Kounivsky G, Lin G, Zbar A et al. (2017) Percutaneous cholecystostomy in the management of high-risk patients presenting with acute cholecystitis: Timing and outcome at a single institution. Am J Surg 214: 456-461. [Crossref]

8. Hasbahceci M, Cengiz MB, Malya FU, Kunduz E, Memmi N (2018) The impact of a percutaneous cholecystostomy catheter in situ until the time of cholecystectomy on the development of recurrent acute cholecystitis: a historical cohort study. Rev Esp Enferm Dig 110: 629633. [Crossref]

9. Koebrugge B, van Leuken M, Ernst MF, van Munster I, Bosscha K (2010) Percutaneous cholecystostomy in critically ill patients with a cholecystitis: a safe option. Dig Surg 27: 417-421. [Crossref]

10. Jang WS, Lim JU, Joo KR, Cha JM, Shin HP et al. (2015) Outcome of conservative percutaneous cholecystostomy in high-risk patients with acute cholecystitis and risk factors leading to surgery. Surg Endosc 29: 2359-2364. [Crossref]

11. Morse BC, Smith JB, Lawdahl RB, Roettger RH (2010) Management of acute cholecystitis in critically ill patients: contemporary role for cholecystostomy and subsequent cholecystectomy. Am Surg 76: 708712. [Crossref]

12. Popowicz A, Lundell L, Gerber P, Gustafsson U, Pieniowski E et al. (2016) Cholecystostomy as Bridge to Surgery and as Definitive Treatment or Acute Cholecystectomy in Patients with Acute Cholecystitis. Gastroenterol Res Pract 2016: 3672416. [Crossref]

13. Molavi I, Schellenberg A, Christian F (2018) Clinical and operative outcomes of patients with acute cholecystitis who are treated initially with image-guided cholecystectomy. Can J Surg 61: 195-199. [Crossref]

14. Ignatavicius P, Kiudelis M, Dekeryte I, Mikuckyte D, Sasnauskaite J et al. (2019) Percutaneous cholecystostomy is a reasonable alternative for treatment of acute cholecystitis in critically ill patients: a single center analysis. Lietuvos chirurgija 18: 246-253.

15. Kim D, Iqbal SI, Ahari HK, Molgaard CP, Flake S et al. (2018) Expanding role of percutaneous cholecystotomy and interventional radiology for the management of acute cholecystitis: An analysis of 144 patients. Diagn Interv Imaging 99: 15-21. [Crossref]

16. Jung W, Park DE (2015) Timing of cholecystectomy after percutaneous cholecystectomy for acute cholecystitis. Korean J Gastroenterol 66: 209-214. [Crossref]

17. Masrani A, Young D, Karageorglou, Mani NB, Picus DD et al. (2020) Management algorithm of acute cholecystitis after percutaneous cholystectomy catheter placement based on outcomes from 377 patients. Abdom Radiol (NY) 45: 1193-1197. [Crossref]

18. Chok KS, Chu FS, Cheung TT, Lam VW, Yuen WK et al. (2010) Results of percutaneous transhepatic cholecystostomy for high surgical risk patients with acute cholecystitis. ANZ J Surg 80: 280-283. [Crossref]

19. Sanjay P, Mittpalli D, Marioud A, White RD, Ram R et al. (2013) Clinical outcomes of a percutaneous cholecystostomy for acute cholecystitis: a multicentre analysis. HPB (Oxford) 15: 511-516. [Crossref]

20. Suzuki K, Bower M, Cassaro S, Patel RI, Karpeh MS et al. (2015) Tube cholecystostomy before cholecystectomy for the treatment of acute cholecystitis. JSLS 19: e2014.00200. [Crossref]

21. Pal KMI, Ali A, Bari H (2018) Role of percutaneous cholecystostomy tube placement in the management of acute calcolous cholecystitis in high risk patients. J Coll Physicians Surg Pak 28: 386-389. [Crossref]

22. Yoon HK (2013) Acute cholecystitis: we can drain it! Gastrointest Interv 2: 47-49.

23. Jones Q, Fowler H, Abbott G, Saha S, Evans J et al. (2019) Short-term outcomes in percutaneous cholecystostomies: a retrospective cohort study. Int Surg J 6: 1-8.

24. Imanzadeh A, Kokabi N, Pourjabbar S, Latich I, Pollak J et al. (2020) Safety and Efficacy of Percutaneous Cholecystostomy for Emphysematous Cholecystitis. J Clin Imaging Sci 10: 9. [Crossref]

25. El Hadidi A, Negm A, Halim MA, Basheer M, Samir M et al. (2019) Cholecystectomy versus percutaneous cholecystostomy drainage in critically ill patients with acute calcolous syndrome: a comparative study. Egipt J Surg 38: 46-51.

26. Horn T, Christensen SD, Kirkegård J, Larsen LP, Knudsen AR et al. (2015) Percutaneous cholecystotomt is an effective treatment option for acute calculous cholecystitis: a 10-year experience. HPB 17: 326-331. [Crossref]

27. Dvorak P, Hoffmann P, Renc O, Dusec T, Rejchrt S et al. (2019) Percutaneous cholecystectomy in the management of acute cholecystitis-10 years of experience. Wideochir Inne Tech Maloinwazyjne 14: 516-525. [Crossref]

28. Winbladh A, Gullstrand P, Svanvik J, Sandstrom P (2009) Systematic review of cholecystostomy as a treatment option in acute cholecystitis. HPB 11: 183-193. [Crossref]

29. Dimou FM, Adhikari D, Mehta HB, Riall TS (2017) Outcomes in Older Patients with Grade III Cholecystitis and Cholecystostomy Tube Placement: A Propensity Score Analysis. J Am Coll Surg 224: 502.e1 511.e1. [Crossref]

30. Gurusamy KS, Rossi KS, Davidson BR (2013) Percutaneous cholecystostomy for high-risk surgical patients with acute calcolous cholecystitis. Cochrane Database Syst Rev CD007088. [Crossref]

31. Gulaya K, Shamit SD, Kent S (2016) Percutaneous cholecystostomy: Evidence-based current clinical Practice. Semin Intervent Radiol 33: 291-296. [Crossref]

32. Venara A, Carretier V, Lebigot J, Lermite E (2014) Technique and indications of percutaneous cholecystostomy in the management of cholecystitis in 2014. J Vasc Surg 151: 435-439. [Crossref]

33. Krishnamoorthi R, Jayaraj M, Chandrasekar VT, Singh D, Law J et al. (2020) EUS-guided versus endoscopic transpapillary gallbladder drainage in high-risk surgical patients with acute cholecystitis: a systematic review and meta-analysis. Surg Endosc 34: 1904-1913. [Crossref] 
34. Itoi T, Takada T, Hwang TL, Endo I, Akazawa K et al. (2017) Percutaneous and endoscopic gallbladder drainage for acute cholecystitis: international multicenter comparative study using propensity score-matched analysis. J Hepatobiliary Pancreat Sci 24: 362-368. [Crossref]

35. Wang B, Guo Z, Liu Z, Wang Y, Si Y et al. (2013) Preoperative versus intraoperative endoscopic sphincterotomy in patients with gallbladder and suspected common bile duct stones: systematic review and metaanalysis. Surg Endosc 27: 2454-2465.

36. Kortram K, van Ramshorst B, Bollen TL, Besselink MGH, Gouma DJ et al. (2012) Acute cholecystitis in high risk surgical patients: percutaneous cholecystostomy versus laparoscopic cholecystectomy (CHOCOLATE trial): Study protocol for a randomized controlled trial. Trials 13: 7. [Crossref]

37. Loozen CS, van Santvoort HC, van Duijvendijk P, Besselink MGH, Gouma DJ et al. (2018) Laparoscopic cholecystectomy versus percutaneous catheter drainage for acute cholecystitis in high risk patients (CHOCOLATE): multicentre randomised clinical trial. BMJ 363: k3965. [Crossref]

38. Griniatsos J, Petrou A, Pappas P, Revenas K, Karavokyros I et al. (2008) Percutaneous cholecystostomy without interval cholecystectomy as definitive treatment of acute cholecystitis in elderly and critically ill patients. South Med J 101: 586-590. [Crossref]

39. Granlund A, Karlson BM, Elvin A, Rasmussen I (2001) Ultrasoundguided percutaneous cholecystostomy in high-risk surgical patients. Langenbecks Arch Surg 386: 212-217. [Crossref]

40. Leveau P, Andersson E, Carlgren I, Willner J, Andersson R (2008) Percutaneous cholecystostomy: a bridge to surgery or definite management of acute cholecystitis in high risk patients? Scand $J$ Gastroenterol 43: 593-596. [Crossref]

41. Peters R, Kolerman S, Peters B, Simoens M, Braak S (2014) Percutaneous cholecystostomy: single centre experience in 111 patients with an acute cholecystitis. JBR-BTR 97: 197-201. [Crossref]

42. Lee SI, Na BG, Yoo YS, Mun SP, Choi NK (2015) Clinical outcome for laparoscopic cholecystectomy in extremely elderly patients. Ann Surg Treat Res 88: 145-151. [Crossref]
43. ASGE Standards of Practice Committee, Buxbaum JL, Fehmi SMA, Sultan S, Fishman DS et al. (2019) ASGE guideline on the role of endoscopy in the evaluation and management of choledocolithiasis. Gastrointest Endosc 89: 1075.e15 -1110.e15. [Crossref]

44. Williams E, Beckingham I, El Sayed G, Gurusamy K, Sturgess R et al. (2017) Update guideline on the management of common bile duct stones. Gut 66: 765-782. [Crossref]

45. McKay A, Abulfaraj M, Lipschitz J (2012) Short- and long-term outcomes following percutaneous cholecystostomy for acute cholecystitis in high-risk patients. Surg Endosc 26: 1343-1345. [Crossref]

46. Charlson ME, Pompei P, Ales KL, MacKenzie CR (1987) A new method of classifying prognostic comorbidity in longitudinal studies: development and validation. J Chronic Dis 40: 373-383. [Crossref]

47. De Geus T, Moriarty HK, Waters PS, O'Reilly MK, Lowler L et al. (2020) Outcomes of Patients Treated With Upfront Cholecystostomy for Severe Acute Cholecystitis. Surg Laparosc Endosc Percutan Tech 30: 79-84. [Crossref]

48. Alotaibi AM, Nafea O, Deeb AM, Yousef Z (2019) Is cholecystostomy tube insertion a real bridge for cholecystectomy in acute cholecystitis? A retrospective cohort study. Saudi J Health Sci 8: 157-161.

49. Dai Y, Arellano RS (2017) Current Status of Percutaneous Cholecystostomy for the Management of Cholecystitis. Dig Dis Interv 1: 22-27.

50. Zeren S, Bayhan Z, Koçak G, Kesici U, Korkmaz M et al. (2017) Bridge treatment for early cholecystectomy in geriatric patients with acute cholecystitis: Percutaneous cholecystostomy. Ulus Travma Acil Cerrahi Derg 23: 501-506. [Crossref]

51. Bala M, Mizrahi I, Mazeh H, Yuval J, Eid A et al. (2016) Percutaneous cholecystostomy is safe and effective option for acute calculous cholecystitis in select group of high-risk patients. Eur J Trauma Emerg Surg 42: 761-766. [Crossref]

52. Mizrahi I, Mazeh H, Yuval JB, Almogy G, Bala M et al. (2015) Perioperative outcomes of delayed laparoscopic cholecystectomy for acute calculous cholecystitis with and without percutaneous choelcystostomy. Surgery 158: 728-735. [Crossref] 